\title{
JUURNAL_RU
}

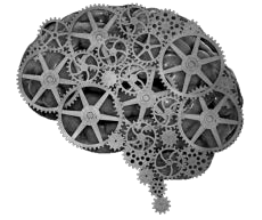

COMPANY GROUP "INTELLEKT"

\author{
Кулакова А.Б. \\ Институт социально-экономического развития территорий Российской академии \\ наук \\ Вологда, Россия
}

doi: 10.18411/lj2016-7-1-12

idsp 000001: lj2016-16-1-12

\section{Психолого-педагогическое сопровождение как развивающий компонент образовательного процесса}

Ситуация современного школьного образования на сегодняшний момент такова, что реализовать приоритетную его цель - воспитание гармоничной и целостной личности - возможным становится, исключительно считаясь с широким влиянием научно-технического прогресса и инновационной политики. Цель учебного процесса в настоящее время не просто достижение определенного уровня знаний, умений, навыков, а что не менее важно создание условий и собственно осуществление развития индивидуальности личности школьника [2]. Таким образом, актуализируется значимость развивающего компонента в образовании, в особенности - степень его выраженности в учебном процессе. Чтобы выстроить и осуществить образовательный процесс, позволяющий полноценно формировать и развивать личностные качества ребенка, возникает необходимость в построенииэффективной системы. Отсюда следует, что в образовании должна присутствовать структура, основной миссией которой является обеспечение развивающего характера образования [1]. Эту функцию берет на себя психологопедагогическое сопровождение обучающихся в образовательном процессе. 
Под психолого-педагогическим сопровождением понимается целостная, системно организованная деятельность, в процессе которой создаются социально-психологические и педагогические условия для успешного обучения и развития каждого ребенка в образовательной среде [3].Роль психологопедагогического сопровождения заключается в обеспечении развивающего характера образования, т. е. создании особых условий в образовательном пространстве, обеспечивающих психологическое благополучие участников образовательного процесса, сохранение их психического и психологического здоровья, предполагающего полноценное личностное развитие на всех возрастных этапах.Организацияпсихолого-педагогического сопровожденияучастников образовательного процесса (школьников, педагогов) является одним из компонентов функционирования Научно-образовательного центра экономики и информационных технологий ИСЭРТ РАН (далее НОЦ ИСЭРТ РАН). К 2016 г. сложилась многоаспектная система сопровождения, направленная на профессионально-личностное развитие и обеспечивающая психологический комфорт участников образовательного процесса(рис. 1).

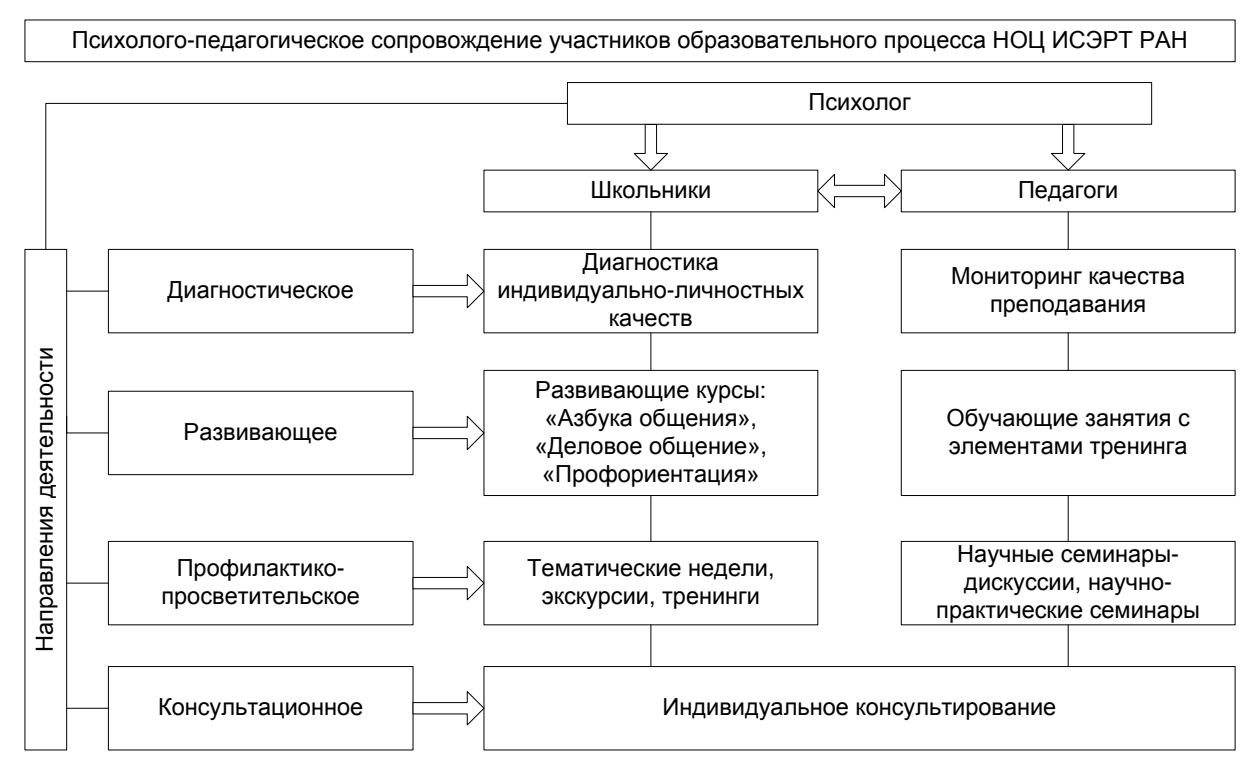

Рис. 1. Система комплексного психолого-педагогического сопровождения школьников и педагогов в образовательном процессе НОЦ ИСЭРТ РАН

Таким образом, деятельность психолого-педагогического сопровождения является структурным и развивающим компонентом образовательного 
процесса. Практическая реализация всех направлений способствует всестороннему, полноценному и гармоничному развитию личности каждого участника образовательного процесса.

\section{Литература:}

1. Беличева, С.А. Служба социальной защиты семьи и детства [Текст] / С.А. Беличева // Педагогика. - 2002.- № 7/8 - С. 23-27.

2. Социально-психологические и педагогические проблемы развития личности учащейся молодежи [Текст] : материалы Региональной научнопрактической конференции, г. Ставрополь, 2.10.2002 г., в 2 т. Ставрополь: Изд-во СГУ, 2002.

3. Щеголь, В.И. Психолого-педагогическое сопровождение образовательного процесса гимназии [Текст] / В.И. Щёголь // Фундаментальные исследования. - 2008. - № 9 - С. 89-91. 